\title{
PENGARUH HYPNOTERAPI TERHADAP PERILAKU BERHENTI MEROKOK PADA MAHASISWA S1 KESEHATAN MASYARAKAT UNIVERSITAS MUHAMMADIYAH KALIMANTAN TIMUR
}

\author{
Sri Sunarti ${ }^{*}$, Noorjannah* \\ Email: srisunarti@umkt.ac.id \\ noorjanah970@gmail.com
}

\begin{abstract}
ABSTRAK
Kebiasaan merokok telah menjadi kebutuhan hidup yang tidak bisa ditinggalkan bagi sebagian orang, namun dilain pihak merokok dapat menimbulkan dampak buruk bagi perokok itu sendiri dan orang yang ada disekitarnya. Hypnoterapi merupakan salah satu alternatif yang dapat digunakan untuk menghentikan kebiasan merokok dengan cara mengubah perilaku orang. Tujuan penelitian ini adalah untuk mengetahui pengaruh hypnoterapi terhadap perilaku berhenti merokok pada mahasiswa S1 Kesehatan Masyarakat Universitas Muhammadiyah Kalimantan Timur.

Jenis penelitian dalam penelitian ini adalah penelitian kuantitatif menggunakan metode penelitian quasi eksperiment dengan rancangan pre-test post-test with control group design. Jumlah sampel sebanyak 36 responden yang diambil menggunaakan teknik probability sampling dengan jenis proportionate stratified random sampling.

Terdapat pengaruh hypnoterapi terhadap pengetahuan, sikap dan tindakan berhenti merokok mahasiswa S1 Kesehatan Masyarakat Universitas Muhammadiyah Kalimantan Timur.
\end{abstract}

Kata Kunci : Hypnoterapi, Perilaku Berhenti Merokok

\section{ABSTRACT}

Smoking behavior have become a necessity of life that cannot be left behind for some people, but on the other hand smoking can have a negative impact on smokers themselves and those around them. Hypnotherapy is an alternative that can be used to stop smoking behavior by changing people's behavior. The purpose of this study was to determine the effect of the hypnotherapy on stopping smoking behavior in undergraduate students of Public Health at the Universitas Muhammaadiyh Kalimantan Timur.

The type of research in this study is quantitative research using a quasiexperimental research method with a pre-test post-test with control group design. The number of samples of 36 respondents taken using probability sampling techniques with the type of proportionate stratified random sampling.

There are effects of hypnotherapy on knowledge, attitudes and actions to stop smoking S1 Public Health students at Universitas Muhammadiyah Kalimantan Timur.

Keywords: Hypnotherapy, Behavior to Stop Smoking

\section{PENDAHULUAN}

Kebiasaan merokok telah menjadi kebutuhan hidup yang tidak bisa ditinggalkan bagi sebagian orang, namun dilain pihak merokok dapat menimbulkan dampak buruk bagi perokok itu sendiri dan orang yang ada disekitarnya (Mahdalena et al., 2015). Berdasarkan data WHO pada tahun 2015, Negara ASEAN dinyatakan sebagai kawasan dengan prevalensi $10 \%$ dari seluruh perokok dunia dan $20 \%$ penyebab kematian global akibat tembakau. $\mathrm{Di}$ Indonesia proporsi penduduk yang mengkonsumsi tembakau (hisap dan kunyah) usia $\geq 15$ tahun cenderung meningkat pada tahun 2010 sebesar 34,3\%, meningkat menjadi $36,3 \%$ pada tahun 2013.

*. Kesehatan Masyarakat Universitas Muhammadiyah Kalimantan Timur 
Sedangkan pada tahun 2018 terjadi penurunan sebesar 33,8\% (Riskesdas, 2018). Menurut data Susenas yang dilakukan BPS Samarinda tahun 2017, persentase penduduk usia $\geq 15$ tahun yang merokok sebesar $25,37 \%$, dengan rata-rata batang rokok yang dihisap perminggu berjumlah 91,48 batang.

Berhenti merokok merupakan suatu hal yang tidak mudah dilakukan bagi pecandu rokok, sehingga menjadi perhatian penuh para ahli psikologi dengan memasukkan adiksi sebagai salah satu dari divisi kajian American Pyshological Association (APA). Sehingga intervensi psikologi dalam bentuk psikoterapi dapat berkembang salah satunya hypnoterapi (Blaise, 2016).

Hypnoterapi merupakan salah satu alternatif yang dapat digunakan untuk menghentikan kebiasan merokok dengan cara mengubah perilaku orang. Dimana pada saat seseorang dalam keadaan trance akan diberikan perlakukan untuk melemahkan keinginan untuk merokok (Mohamed \& ElMwafie, 2015). Kegiatan manusia dalam keseharian banyak dipengaruhi oleh pikiran. Pikiran manusia terbagi dua yaitu, pikiran alam sadar dan pikiran alam bawah sadar. Seorang ahli ilmu psikologi asal India Utara, Prof dr Kelvan Vinath menyatakan bahwa pikiran bawah sadar mempunyai kekuatan $70 \%$ dibanding dengan pikiran sadar yang memiliki kekuatan 30\% (Budiman, 2016).

Berdasarkan survei awal yang dilakukan peneliti di program studi S1 Kesehaan Masyarakat terdapat sebanyak 107 orang jumlah mahasiswa laki-laki. Sekitar $52 \%$ atau sebanyak 56 orang jumlah laki-laki yang mengkonsumsi rokok konvensional maupun rokok elektrik.

Berdasarkan urain diatas, maka peneliti tertarik untuk melakukan penelitian mengenai "Pengarauh Hypnoterapi Terhadap Perilaku Berhenti Merokok Pada Mahasiswa S1 Kesehatan Masyarakat Universitas Muhammadiyah Kalimantan Timur". Adapun tujuan penelitian ini untuk mengetahui pengaruh hypnoterapi terhadap perilaku berhenti merokok pada mahasiswa S1 Kesehatan Masyarakat Universitas Muhammadiyah Kalimantan Timur.

\section{METODE PENELITIAN}

Jenis penelitian ini adalah penelitian kuantitatif menggunakan metode penelitian quasi eksperiment dengan rancangan pre-test post-test with control group design. Populasi pada penelitian ini berjumlah 56 responden dengan sampel sebanyak 36 responden yang diambil menggunakan teknik probability sampling dengan jenis proportionate stratified random sampling. Kelompok ekperimen terdiri dari mahasiswa laki-laki yang merokok di Program Studi S1 Kesehatan Masyarakat Universitas Muhammadiyah Kalimantan Timur. Sedangkan pada kontrol ekperimen terdiri dari mahasiswa laki-laki yang merokok di Program Studi S1 Kesehatan Masyarakat Universitas Widiagama Samarinda.

Instrumen pengumpulan data adalah lembar kuesioner yang berisi data demografi meliputi umur, mulai merokok dan jumlah rokok yang di konsumsi setiap hari, pertanyaan pengetahuan, sikap dan tindakan. Hypnoterapi dilakukan oleh hypnoterapis (ahli terapis) dengan durasi waktu satu jam. Hypnoterapi dilakukan secara massal kepada responden, tetapi jika ada responden yang mengalami perubahan dalam dirinya seperti mual, pusing dan lainya responden tersebut akan diberikan hypnoterapi secara individu. Pada saat proses hypnoterapi dilakukan ahli terapis memasukan kalimat-kalimat tentang apa itu rokok, dampak dari rokok dan lainnya.

Uji validitas kuesioner dilakukan

di Program Studi S1 Kesehatan Lingkungan Universitas Muhammadiyah Kalimantan Timur. Uji hasil validitas kuesioner untuk pengetahuan dari 15 pertanyaan ada 13 pertanyaan yang valid, sikap dari 15 pernyataan ada 14 pernyataan yang valid dan untuk tindakan dari 8 petanyaan semuanya valid. Uji normalitas data menggunakan sofware statistik yang hasilnya menunjukkan bahwa data berdistrbusi tidak normal, sehingga uji statistik yang digunakan dalam penelitian ini adalah uji Wilcoxon dan uji Mann-Whitney. 
HASIL

\section{Karateristik Responden}

Tabel 1

Distribusi Karateristtik Responden

\begin{tabular}{lcccc}
\hline \multicolumn{1}{c}{ Karateristik } & \multicolumn{2}{c}{ Eksperimen } & \multicolumn{2}{c}{ Kontrol } \\
\hline Umur & $\mathbf{N}$ & $\mathbf{\%}$ & $\mathbf{N}$ & $\mathbf{\%}$ \\
\hline 18 Tahun & 4 & $11.1 \%$ & 5 & $13.9 \%$ \\
19 Tahun & 7 & $19.4 \%$ & 11 & $30.6 \%$ \\
20 Tahun & 7 & $19.4 \%$ & 12 & $33.3 \%$ \\
21 Tahun & 6 & $16.7 \%$ & 6 & $16.7 \%$ \\
22 Tahun & 10 & $27.8 \%$ & 2 & $5.6 \%$ \\
23 Tahun & 1 & $2.8 \%$ & 0 & $0 \%$ \\
24 Tahun & 1 & $2.8 \%$ & 0 & $0 \%$ \\
Mulai Merokok & & & & \\
TK & 0 & $0 \%$ & 1 & $2.8 \%$ \\
SD & 8 & $22.2 \%$ & 4 & $11.1 \%$ \\
SMP & 10 & $27.8 \%$ & 13 & $36.1 \%$ \\
SMA & 18 & $50 \%$ & 18 & $50 \%$ \\
Jumlah Rokok & & & & \\
Ringan (1-4 batang/hari) & 22 & $61.1 \%$ & 28 & $77.8 \%$ \\
Sedang (5-14 batang/hari) & 13 & $36.1 \%$ & 6 & $16.7 \%$ \\
Berat (>15 batang/hari) & 1 & $2.8 \%$ & 2 & $5.6 \%$ \\
\hline
\end{tabular}

Berdasarkan tabel 1 diatas, karateristik umur responden pada kelompok eksperimen dengan jumlah tertinggi adalah umur 22 tahun sebanyak 10 orang $(27.8 \%)$, sedangkan pada kelompok kontrol dengan jumlah tertinggi adalah umur 20 tahun sebanyak 12 orang (33.3\%). Pada karateristik mulai merokok frekuensi terbesar responden pada kelompok eksperimen dan kelompok kontrol mulai merokok pada saat SMA sebanyak 18 orang (50\%). Sedangkan pada karateristik jumlah rokok yang dikonsumsi setiap hari jumlah terbesar adalah perokok ringan (1-4 batang/hari) sebanyak 22 orang $(61.1 \%)$ pada kelompok eksperimen dan sebanyak 28 orang $(77.8 \%)$ pada kelompok kontrol.

\section{Analisis Univariat}

Tabel 2

Distribusi Nilai Pengetahuan, Sikap dan Tindakan Kelompok Eksprimen dan Kontrol

\begin{tabular}{llcccccc}
\hline \multirow{2}{*}{ Frekuensi } & \multicolumn{2}{c}{ Pengetahun } & \multicolumn{2}{c}{ Sikap } & \multicolumn{2}{c}{ Tindakan } \\
\cline { 3 - 8 } Mean & Eksperimen & Kontrol & Eksperimen & Kontrol & Eksperimen & Kontrol \\
\hline \multirow{2}{*}{ Median } & Pretest & 11.25 & 12.17 & 43.64 & 42.94 & 3.47 & 3.78 \\
\cline { 2 - 8 } & Posttest & 12.72 & 12.64 & 50.44 & 43.28 & 4.81 & 4.19 \\
\multirow{2}{*}{ St. Deviaion } & Pretest & 11.50 & 13.00 & 43.50 & 43.00 & 3.50 & 4.00 \\
\multirow{3}{*}{ Minimum } & Posttest & 13.00 & 13.00 & 51.44 & 42.00 & 5.00 & 4.00 \\
& Pretest & 1.360 & 1.558 & 4.402 & 5.042 & 1.158 & 1.376 \\
\multirow{2}{*}{ Maximum } & Posttest & .045 & .723 & 4.272 & 4.366 & .401 & .889 \\
& Pretest & 7 & 6 & 35 & 23 & 2 & 0 \\
& Posttest & 12 & 11 & 40 & 38 & 4 & 2 \\
& Pretest & 13 & 13 & 51 & 53 & 5 & 5 \\
\hline
\end{tabular}

Nilai Pengetahuan Kelompok Eksperimen dan Kontrol

Berdasarkan pada tabel 2, pada kelompok eksperimen nilai mean sebelum diberikan perlakuan yaitu 11.25 dengan nilai median yaitu 11.50. Nilai minimum yaitu 7 dan nilai maksimum yang dicapai yaitu 13. Sedangkan setelah diberikan perlakuan, nilai mean yaitu 12.72 dengan nilai median yaitu 13.00. Nilai minimum yaitu 12 dan nilai maksimum yang dicapai yaitu 13. Selisih mean pada pretest dan posttest adalah 1.47 , sehingga dapat terlihat bahwa ada perbedaan pengetahuan mahasiswa sebelum dan sesudah diberikan perlakukan.

Pada kelompok kontrol didapatkan data bahwa nilai mean pada saat pretest yaitu 12.17 dengan nilai median yaitu 13.00 . Nilai minimum yaitu 6 dan nilai maksimum yang dicapai yaitu 13. Sedangkan nilai mean pada saat posttest yaitu 12.64 dengan nilai median yaitu 13.00. Nilai minimum yaitu 11 dan nilai maksimum yang dicapai yaitu 13 . Selisih mean pada pretest dan posttest adalah 0.47, sehingga dapat terlihat bahwa ada perbedaan pengetahuan pada kelompok kontrol yang tidak diberikan 
perlakuan sehingga nilai yang didapatkan tidak signifikan.

Nilai Sikap Kelompok Eksperimen dan Kontrol

Berdasarkan pada tabel 2, pada kelompok eksperimen nilai mean sebelum diberikan perlakuan yaitu 43.64 dengan nilai median yaitu 43.50. Nilai minimum yaitu 35 dan nilai maksimum yang dicapai yaitu 51. Sedangkan setelah diberikan perlakuan, nilai mean yaitu 50.44 dengan nilai median yaitu 51.50. Nilai minimum yaitu 40 dan nilai maksimum yang dicapai yaitu 56 . Selisih mean pada pretest dan posttest adalah 6.8 , sehingga dapat terlihat bahwa ada perbedaan sikap mahasiswa sebelum dan sesudah diberikan perlakukan.

Pada nilai sikap didapatkan data bahwa nilai mean pada saat pretest yaitu 42.94 Pada kelompok kontrol didapatkan data bahwa nilai mean pada saat pretest yaitu 42.94 dengan nilai median yaitu 43.00. Nilai minimum yaitu 23 dan nilai maksimum yang dicapai yaitu 53. Sedangkan nilai mean pada saat posttest yaitu 43.28 dengan nilai median yaitu 42.00. Nilai minimum yaitu 38 dan nilai maksimum yang dicapai yaitu 52 . Selisih mean pada pretest dan posttest adalah 0.34 , sehingga dapat terlihat bahwa ada perbedaan sikap pada kelompok kontrol yang tidak diberikan perlakuan sehingga nilai yang didapatkan tidak signifikan

Nilai Tindakan Kelompok Eksperimen dan Kontrol

Berdasarkan pada tabel 2, pada kelompok eksperimen nilai mean sebelum diberikan perlakuan yaitu 3.47 dengan nilai median yaitu 3.50. Nilai minimum yaitu 2 dan nilai maksimum yang dicapai yaitu 5 . Sedangkan setelah diberikan perlakuan, nilai mean yaitu 4.81 dengan nilai median yaitu 5.00. Nilai minimum yaitu 4 dan nilai maksimum yang dicapai yaitu 5 . Selisih mean pada pretest dan posttest adalah 1.34, sehingga dapat terlihat bahwa ada perbedaan tindakan mahasiswa sebelum dan sesudah diberikan perlakukan.

Pada kelompok kontrol didapatkan data bahwa nilai mean pada saat pretest yaitu 3.78 dengan nilai median yaitu 4.00 . Nilai minimum yaitu 0 dan nilai maksimum yang dicapai yaitu
5. Sedangkan nilai mean pada saat posttest yaitu 4.19 dengan nilai median yaitu 4.00. Nilai minimum yaitu 2 dan nilai maksimum yang dicapai yaitu 5 . Selisih mean pada pretest dan posttest adalah 0.41 , sehingga dapat terlihat bahwa ada perbedaan tindakan pada kelompok kontrol yang tidak diberikan perlakuan sehingga nilai yang didapatkan tidak signifikan.

\section{Analisis Bivariat}

Tabel 3

Pengaruh Hypnoterapi terhadap Pengetahun, Sikap dan Tindakan

\begin{tabular}{llcc}
\hline \multicolumn{1}{c}{ Variabel } & Kelompok & Z & P-Value \\
\hline \multirow{2}{*}{ Pengetahuan } & Eksperimen & -4.704 & 0.000 \\
& Kontrol & -1.616 & 0.106 \\
Sikap & Eksperimen & -4.230 & 0.000 \\
& Kontrol & -0.172 & 0.863 \\
Tindakan & Eksperimen & -4.246 & 0.000 \\
& Kontrol & -1.440 & 0.150 \\
\hline
\end{tabular}

Pengaruh Hypnoterapi Terhadap Pengetahuan

Berdasarkan uji Wilcoxon Sign Rank pada kelompok eksperimen, didapatkan hasil nilai $\mathrm{p}$-value $=0.000<$ 0.05 , sehingga dapat disimpulkan bahwa terdapat pengaruh hypnoterapi terhadap pengetahuan berhenti merokok mahasiswa S1 Kesehatan Masyarakat Universitas Muhammadiyah Kalimantan Timur. Pada kelompok kontrol, didapatkan hasil nilai $p$-value $=0.106>$ 0.05, sehingga dapat disimpulkan bahwa tidak terdapat pengaruh pengetahuan berhenti merokok mahasiswa S1 Kesehatan Masyarakat Universitas Widiagama Samarinda.

Berdasarkan uji Mann-Whitney, didapatkan hasil nilai $\mathrm{p}$-value $=0.007<$ 0.05 , sehingga dapat diambil kesimpulan ada perbedaan pengetahuan berhenti merokok mahasiswa pada kelompok eksperimen dibanding dengan kelompok kontrol.

Pengaruh Hypnoterapi Terhadap Sikap

Berdasarkan uji Wilcoxon Sign Rank pada kelompok eksperimen, didapatkan hasil nilai $p$-value $=0.000<$ 0.05, sehingga dapat disimpulkan bahwa terdapat pengaruh hypnoterapi terhadap sikap berhenti merokok mahasiswa S1 Kesehatan Masyarakat Universitas 
Muhammadiyah Kalimantan Timur. Pada kelompok kontrol, didapatkan hasil nilai $\mathrm{p}$-value $=0.863>0.05$, sehingga dapat disimpulkan bahwa tidak terdapat pengaruh sikap berhenti merokok mahasiswa S1 Kesehatan Masyarakat Universitas Widiagama Samarinda.

Berdasarkan uji Mann-Whitney, didapatkan hasil nilai $\mathrm{p}$-value $=0.000$. $<$ 0.05, sehingga dapat disimpulkan bahwa ada perbedaan sikap berhenti merokok mahasiswa pada kelompok eksperimen dibanding dengan kelompok kontrol.

Pengaruh Metode Hypnoterapi Terhadap Tindakan

Berdasarkan uji Wilcoxon Sign Rank pada kelompok eksperimen, didapatkan hasil nilai $\mathrm{p}$-value $=0.000<$ 0.05, sehingga dapat disimpulkan bahwa terdapat pengaruh hypnoterapi terhadap tindakan berhenti merokok mahasiswa S1 Kesehatan Masyarakat Universitas Muhammadiyah Kalimantan Timur. Pada kelompok kontrol, didapatkan hasil nilai $\mathrm{p}$-value $=0.150>0.05$, sehingga dapat disimpulkan bahwa tidak terdapat pengaruh tindakan berhenti merokok mahasiswa S1 Kesehatan Masyarakat Universitas Widiagama Samarinda.

Berdasarkan uji Mann-Whitney, didapatkan hasil nilai $\mathrm{p}$-value $=0.001<$ 0.05 , sehingga dapat disimpulkan bahwa ada perbedaan tindakan berhenti merokok mahasiswa pada kelompok eksperimen dibanding dengan kelompok kontrol.

\section{PEMBAHASAN}

\section{Pengaruh hypnoterapi terhadap pengetahuan berhenti merokok}

Pengetahuan tentang bahaya merokok merupakan pengetahuan yang dimiliki seseorang mengenai zat yang ada dalam kandungan rokok, dampak yang ditimbulkan oleh perilaku merokok dan pengetahuan umum seputar rokok (Chotidjah, 2012).

Berdasar hasil penelitian menggunakan uji Wilcoxon Sign Rank, didapatkan hasil bahwa terdapat pengaruh hypnoterapi terhadap pengetahuan berhenti merokok pada kelompok eksperimen. Sedangkan pada kelompok kontrol, didapatkan hasil bahwa tidak terdapat pengaruh pengetahuan berhenti merokok.
Adapun hasil yang didapatkan pada kelompok eksperimen yaitu terjadi peningkatan nilai pengetahuan setelah diberikan perlakukan metode hypnoterapi. Sedangkan pada kelompok kontrol juga mengalami peningkatan namun tidak signifikan karena tidak diberikan perlakukan apapun. Uji hasil Mann-Whitney didapatkan hasil nilai $\mathrm{p}$ value sebesar $0.007>0.05$, sehingga dapat disimpulkan bahwa ada perbedaan pengetahuan berhenti merokok mahasiswa pada kelompok eksperimen dibanding dengan kelompok kontrol.

Pada saat proses hypnoterapi dilakukan hipnoterapis memasukkan kalimat- kalimat tentang apa itu rokok, dampak dari rokok dan lainnya. Dengan memberikan kalimat-kalimat seperti itu dapat menambah pengetahuan seseorang. Hal ini sesui dengan pendapat Soekanto (2004) yang menyatakan bahwa seseorang dengan banyak memiliki informasi dapat menjadikan seseorang memiliki pengetahuan yang luas.

Hal ini sesuai dengan teori pengetahuan yaitu hasil penginderaan seseorang atau hasil dari tahu terhadap suatu obyek tertentu melalui pancaindra yang dimilikinya yakni perasa, peraba, penglihatan, pendengaran dan penciuman. Bagian terpenting untuk memperoleh pengetahuan adalah melalui mata dan telinga. Bagian terpenting untuk tindakan seseorang adalah pengetahuan, karena dari suatu penelitian serta pengalaman ternyata perilaku seseorang didasarkan oleh pengetahuan akan lebih kekal dibandingkan perilaku yang tanpa didasari oleh pengtahuan, sedangkan dalam tingkat pengetahuan terdapat ada 6 tingkatan yakni tahu, memahami, aplikasi, analisis, sintesis dan evaluasi (Notoatmodjo, 2005).

Peningkatan

pengetahuan seseorang dipengaruhi oleh beberapa faktor yaitu media massa, lingkungan, pengalaman pribadi atau orang lain, dan pendidikan (Notoatmodjo, 2012). Kelompok kontrol telah mendapatkan informasi dari berbagai media massa atau pengalaman pribadinya yang merupakan perokok ringan (1-4 batang/hari), sehingga hal tersebut menjadi salah satu faktor tidak adanya 
pengaruh pengetahun berhenti merokok. Hipnosis merupakan suatu keadaan santai ataupun konsentrasi, ciri khas dari kondisi tersebut ialah sensorsensor pancaindra manusia menjadi jauh lebih aktif. Hipnosis adalah kondisi ketika seseorang lebih mudah menerima saran, informasi, dan sugesti yang mampu mengubah seseorang dari hal yang kurang baik menjadi hal yang baik (Hasbullah \& Rahmawati, 2015).

Menurut hasil survei yang dilakukan peneliti didapatkan bahwa di Universitas Muhammadiyah Kalimantan Timur belum ada klinik berhenti merokok dengan metode hypnoterapi untuk meningkatkan pengetahuan, sehingga perlu di bentuk sarana klinik berhenti merokok dengan metode hypnoterapi untuk dapat menambah pengetahuan mengenai berhenti merokok.

\section{Pengaruh hypnoterapi terhadap sikap berhenti merokok}

Sikap ialah respon seseorang yang tertutup terhadap stimulus atau objek tertentu yang melibatkan suatu faktor pendapat atau emosi yang bersangkutan seperti setuju

- tidak setuju, baik - tidak baik dan sebagainya (Notoatmodjo, 2005). Memberikan sugesti merupakan salah satu upaya untuk merubah sikap seseorang. Dalam meningkatkan sugesti sebagai efek sikap pada seseorang dilakukan hipnosis agar seseorang mempunyai sugestibilitas yang baik dan dapat mempengaruhi sikap yang positif (Mulyana \& Azizah, 2014).

Berdasarkan hasil uji statisik menggunakan uji Wilcoxon Sign Rank, didapatkan bahwa terdapat pengaruh hypnoterapi terhadap sikap berhenti merokok pada kelompok eksperimen. Hal ini sesuai dengan penelitian yang dilakukan oleh Fourianalistyawati (2012), yang menunjukkan bahwa pemberian hypnoterapi klinis dapat menurunkan depresi pada pecandu narkoba di UPT T\&R BNN.

Pada kelompok kontrol hasil uji statistik menggunakan uji Wilcoxon Sign Rank, didapatkan hasil bahwa tidak terdapat pengaruh sikap berhenti merokok. Tidak adanya pengaruh pada kelompok kontrol karena tidak diberikan perlakukan apapun. Pengetahuan pada kelompok kontrol tidak terdapat perubahan sehingga sikap juga tidak terdapat perubahan untuk perilaku berhenti merokok. Hal ini sesuai dengan pendapat Wawan (2010) yang menyatakan bahwa perubahan sikap yang semakin baik dipengaruhi pengetahuan, sehingga dapat dikatakan jika pengetahuan baik maka sikap semakin baik, tetapi sebaliknya jika pengetahuan tidak baik maka sikap juga tidak baik.

Adapun hasil yang didapatkan pada kelompok eksperimen yaitu terjadi peningkatan nilai sikap setelah diberikan perlakukan metode hypnoterapi. Sedangkan pada kelompok kontrol juga mengalami peningkatan namun tidak signifikan karena tidak diberikan perlakukan apapun. Uji hasil MannWhitney didapatkan hasil nilai $\mathrm{p}$ - value sebesar $0.000>0.05$, sehingga dapat disimpulkan bahwa ada perbedaan sikap berhenti merokok mahasiswa pada kelompok eksperimen dibanding dengan kelompok kontrol.

Seseorang yang telah mengetahui suatu objek, maka proses selanjutnya adalah bersikap terhadap objek tersebut. Tiga komponn sikap yaitu komponen kognitif yang berhubungan kepercayaan, ide dan konsep. Komponen afekif yang berhubungan kehidupan emosional seseorang dan komponen konatif yang merupakan kecenderungan seseorang untuk bertingkah laku (Notoatmodjo, 2012).

Hipnoterapi adalah salah satu teknik terapi pikiran yang menggunakan hipnosis. Kondisi hipnosis ini bekerja di alam bawah sadar untuk memberikan sugesti yang baik dengan tujuan merubah persepsi yang salah dan mendorong untuk berfikir positif dalam menghadapi masalah yang ada (Mulyana \& Azizah, 2014). Sehingga dapat disimpulkan bahwa metode hypnoterapi ini merupakan salah satu strategi yang tepat digunakan untuk seseorang yang ingin berhenti merokok dan hasil penelitian ini juga merupakan salah satu epidenbes dalam pembuatan policy brief untuk mendirikan klinik berhenti merokok dengan strategi hypnoterapi. 


\section{Pengaruh metode hypnoterapi terhadap tindakan berhenti merokok}

Tindakan atau praktek adalah suatu sikap yang belum terwujud dalam tindakan, karena untuk mewujudkan tindakan diperlukan faktor pendukung atau adanya fasilitas (Notoatmodjo, 2007). Kondisi yang memfasilitsi adalah keadaan yang mendukung penuh perilaku seseorang untuk melakukan sesuatu. Misalnya adanya fasilitas yang digunakan sebagai alternatif untuk menghentikan kebiasaan merokok seseoraang dengan cara mengubah perilaku seperti metode hypnoterapi untuk menghentikan kebiasaan merokok (Mohamed \& ElMwafie, 2015).

Berdasarkan hasil uji statistik menggunakan uji Wilcoxon Sign Rank, didapatkan hasil bahwa terdapat pengaruh hypnoterapi terhadap tindakan berhenti merokok pada kelompok eksperimen. Penelitian ini sesuai dengan penelitian yang dilakukan oleh Budiman (2016), yang menyatakan bahwa ada pengaruh hypnoterapi terhadap perubahan perilaku merokok dengan hasil penelitian dari 15 responden 11 orang berhenti merokok sedangkan 2 orang dapat mengurangi intensitas dan frekuensi merokok hingga $78 \%$ sementara untuk 2 orang lagi hanya mampu mampu mengurangi intensitas merokok $56,3 \%$. Penelitian lainnya yang sesuai dengan penelitian ini dilakukan oleh Wulandari (2016), yang menyatakan bahwa bahwa hipnoterapi berpengaruh terhadap penurunan intensitas merokok remaja.

Pada kelompok kontrol hasil uji statistik menggunakan uji Wilcoxon Sign Rank, didapatkan hasil bahwa tidak terdapat pengaruh tindakan berhenti merokok. Tidak adanya pengaruh pada kelompok kontrol karena tidak diberikan perlakukan apapun. Hal ini tidak sesuai dengan penelitian yang dilakukan oleh Elmwafie dan Mohamed (2015), yang menunjukkan bahwa terdapat perbedaan yang sangat signifikan terhadap jumlah perokok.

Adapun hasil yang didapatkan pada kelompok eksperimen yaitu terjadi peningkatan nilai tindakan setelah diberikan perlakukan metode hypnoterapi. Sedangkan pada kelompok kontrol juga mengalami peningkatan namun tidak signifikan karena tidak diberikan perlakukan apapun. Uji hasil Mann-Whitney didapatkan hasil nilai $\mathrm{p}$ value sebesar $0.001>0.05$, sehingga dapat disimpulkan bahwa ada perbedaan tindakan berhenti merokok mahasiswa pada kelompok eksperimen dibanding dengan kelompok kontrol.

Perbedaan keberhasilan berhenti merokok pada seseorang, tergantung penyebab awalnya merokok, lamanya menjadi perokok, jumlah rokok yang dikonsumsi setiap hari, dan kuatnya keinginan untuk merokok.Berhasilnya seseorang dalam usaha untuk tidak merokok didasarkan oleh sejauh mana niatnya untuk berhenti merokok. Niat yang kuat untuk tidak merokok lagi akan menguatkan perokok untuk mengontrol perilakunya dalam situasi apapun pada saat akan melakukan perilaku merokok. Ketika seseorang berniat untuk berhenti merokok, maka bukan hanya dengan membulatkan tekad dan melawan keinginan untuk merokok, melainkan adanya upaya yang harus dilakukan untuk berhenti merokok. Pikiran bawah sadar ikut berpengaruh pada keberhasilan upaya berhenti merokok selain niat (Rosita et al., 2018).

Hypnoterapi adalah suatu aplikasi hipnosis yang dapat menyembuhkan gangguan mental dan meringankan gangguan fisik. hipnosis secara medis dapat mengatasi berbagai macam gangguan psikologis maupun fisik seperti menghilangkan kebiasaan buruk merokok, menghilangkan phobia (Triana, 2014). Kondisi hipnosis menunjukan adanya perubahan yang terjadi pada gelombang otak yang mempengaruhi perilaku manusia. Tingginya pengaruh pikiran sadar terhadap semua aspek kehidupan misalnya sikap, kepribadian, perilaku, kebiasaan, cara pikir, dan keadaan psikis seseorang hanya $10 \%$. Sedangkan besarnya pengaruh pikiran bawah sadar adalah $90 \%$. Pikiran bawah sadar mengendalikan diri kita sembilan kali lebih kuat dibandingkan pikiran sadar (Yudono et al., 2014).

Salah satu strategi promosi kesehatan menurut WHO (1984), yaitu pemberdayaan masyarakat. Tujuan pemberdayaan adalah bentuk usaha agar meningkatkan derajat kesehatannya. Dimana pemberdayan 
masyarakat ini diberikan kepada mahasiswa atau kader-kader kesehatan masyarakat yang dilatih untuk melakukan hypnoterapi. Sehingga dengan adanya kader-kader tersebut akan lebih banyak orang yang di hypnoterapi.

\section{SIMPULAN}

Menurut hasil penelitian dan pembahasaan dapat di tarik kesimpulan yaitu terdapat pengaruh hypnoterapi terhadap pengetahuan, sikap, dan tindakan berhenti merokok pada mahasiswa S1 Kesehatan Masyarakat Universitas Muhammadiyah Kalimantan Timur.

\section{SARAN}

Adapun saran yang dapat disimpulkan adalah sebagai berikut: dapat membentuk sebuah klinik berhenti merokok dengan metode hypnoterapi untuk menambah pengetahuan mengenai berhenti merokok. Dapat menjadi salah satu epidenbes dalam pembuatan policy brief untuk mendirikan klinik berhenti merokok dengan strategi hypnoterapi untuk berhenti merokok. Dapat melakukan pemberdayaan masyarakat dengan membentuk kaderkader yang dilatih untuk melakukan hypnoterapi.

\section{DAFTAR PUSTAKA}

Badan Penelitian dan Kesehatan. Riset Kesehatan Dasar (Riskesdas). (2018). Kementrian Republik Indonesia . Jakarta.

Badan Pusat Statistik Samarinda. Statistik Kesejahteraan Rakyat Kota Samarinda Survei Ekonomi Nasional. (2017).

Blaise, C. F. (2016). Efektifitas Terapi SETF (Spiritual Emotional Freedom Technique) Terhadap Penurunan Intensitas Merokok Di Kinik Berhenti Merokok UPTD Puskesmas Kecamatan Pontianak Kota. Universitas Tanjungpura Pontianak.

Budiman. (2016). Efektifitas Hypnoterapi Teknik Anchor Terhadap Perubahan Perilaku Merokok Remaja ;Studi Pada Klien di Klinik Maulana Center of Hypnotherapy Palembang. Jurnal Psikologi
Islami Vol. 2 No. 2, 135-148.

Chotidjah, S. (2012). Pengetahuan Tentang Rokok, Pusat Kendali Kesehatan Eksternal Dan Perilaku Merokok. Makara, Sosial Humaniora, 16(1), 49-56.

Fourianalistyawati, E. (2012). Efektifitas Hipnoterapi Klinis Untuk Mengatasi Depresi Pada Pecandu Narkoba Di UPT T\&R BNN.

Hasbullah, \& Rahmawati, E. Y. (2015). Pengaruh Penerapan Metode Hynoteaching Terhadap Motivasi Belajar Mahasiswa Universitas Indraprasta PGRI. Jurnal Formatif, 5(1), 83-90.

Mahdalena, Ghozali, M. H., \& Sunarti, S. (2015). Persepsi Masyarakat Terhadap Peringatan Bahaya Merokok Pada Kemasan Rokok Di Wilayah Kerja Puskesmas Air Putih Kota Samarinda. STIKES Muhammadiyah Samarinda.

Mohamed, N. A., \& ElMwafie, S. M. (2015). Effect of hypnotherapy on smoking cessation among secondary school students. Journal of Nursing Education and Practice, 5(2), 67-77. https://doi.org/10.5430/jnep.v5n $2 \mathrm{p} 67$

Mulyana, N., \& Azizah, S. N. (2014). Pengaruh Hypnobreastfeeding Terhadap Sikap Ibu Hamil Trimester II Dalam Pemberian ASI Eksklusif Di Desa Ujungjaya Kecamatan Ujungjaya Kabupaten Sumedang Tahun 2013. Jurnal Kesehatan Kartika, 9(2), 85-92.

Notoatmodjo, S. (2005). Promosi Kesehatan Teori Aplikasi. Jakara: Rineka Cipta.

Notoatmodjo, S. (2007). Promosi Kesehatan dan Ilmu Perilaku. Jakarta: Rineka Cipta.

Notoatmodjo, S. (2012). Promosi Kesehatan dan Perilaku

Cipta. Kesehatan. Jakarta: Rineka

Rosita, R., Suswardany, D. L., \& Abidin, Z. (2018). Jurnal Kesehatan Masyarakat, (April). https://doi.org/10.13140/RG.2.2. 30690.84169

Soekanto. (2004). Teknologi Media Perkembangan Indonesia. Bandung. 
Triana, H. (2014). Efektifitas Hipnoterapi Dalam Mengurangi Tanda Dan Gejala Fobia. IImu Kesehatan, 8(2), 373-382.

Wawan, \& Dewi. (2010). Teori dan Pengukuran Pengetahuan, Sikap dan Perilaku Manusia.

Yogyakarta: Nuha Medika.

WHO. (2015). World Health Statistics: World Health Organization.

Wulandari, A. (2016). Pengaruh
Hipnoterapi Terhadap Penurunan Frekuensi Merokok Pada Remaja. Fakultas Psikologi Universitas Negeri Makassar. Skripsi.

Yudono, D. T., Triana, N. Y., \& Maryoto, M. (2014). Pengaruh Hipnoterapi Terhadap Nyeri Pada Pasien Dispepsia Di RSUD dr. R. Goeteng Taruna Dibrata Purbalingga. Viva Medika, 07. 